renumber the refs at final edit

JTT 09-07-009

RESEARCH/Systematic review

\title{
A systematic review of telemedicine projects in Colombia
}

Carlos Rey Moreno ${ }^{1}$, Javier Simó Reigadas ${ }^{2}$, Estrella Everss Villalba ${ }^{2}$, Juan Jose Vinagre ${ }^{2}$ and Andrés Martínez Fernández ${ }^{2}$

1 Fundación EHAS, Madrid, Spain

2 Departamento de Teoría de la Señal y Comunicaciones, Universidad Rey Juan Carlos, Madrid, Spain

Correspondence:

Professor Andrés Martínez Fernández,

Departamento de Teoría de la Señal y Comunicaciones,

Despacho 123. Edificio de Decanato,

Campus de la Fuenlabrada de la Universidad Rey Juan Carlos,

Camino del Molino S/N 28943,

Fuenlabrada,

Madrid,

Spain

(Fax: +34 91488 7500; Email: andres.martinez@urjc.es)

Running head: Telemedicine in Colombia

Accepted: 


\section{Summary}

A systematic review of telemedicine projects in Colombia is presented, aiming to be able to make recommendations from past experiences. Our study consisted on retrieving projects through an exhaustive search strategy, and then classifying and assessing their evaluations. Results show a country with a lot of institutions, both private and public, including the government, working for the development of the telemedicine in Colombia through more than 45 projects. Health care services have mostly been provided on a telemedicine basis to, at least, 550000 patients, and they have connected more than 650 health care institutions, mainly in deprived areas of the country. Unfortunately, none of these projects has been rigorously evaluated, and no recommendations can be made with a minimum degree of evidence for their support. The proposed methodology is suitable for similar studies about telemedicine evaluation in other developing countries.

\section{Introduction}

Telemedicine projects in Colombia were reviewed in studies conducted in 2001 [2] and in 2003.[7] However, these previous compilations were not systematic reviews, and projects were listed without further analysis. We have therefore updated the previous work. The aim was to identify all the projects carried out in Colombia which provided services via telemedicine. This information may be helpful in future telemedicine work in developing countries.

\section{Methods}

The search strategy of the systematic review comprised four steps. In Step 1, relevant articles were identified from the following databases: MEDLINE, LILACS, Cochrane Library, Current Contents, CINAHL, CUIDEN, Telemedicine Information Exchange (TIE) and IEEExplore. Given the lack of articles from developing countries in indexed publications,[8] other documents were examined, such as references within retrieved articles, and other databases, such as the Centre for Reviews and Dissemination (CRD), the Scientific Electronic Library Online (Scielo), the Royal College of General Practitioners (RCGP), the Association of Telehealth Service Providers (ATSP), the American Telemedicine Association (ATA), and the International Society for Telemedicine (ISFT). The keywords used, in English and Spanish, were Colombia and Colombian and each of the following words: telemedicine, telehealth, ehealth and e-health. When a project was found, it was added to the list together with the contact information of the project manager, or of an alternate person if the project manager could not be identified.

In Step 2, Internet search engines were used to retrieve more projects. The search engine Google was used with the keyword combination, and its translation into Spanish, shown in Table 1, following its order of appearance. When using any combination, the following basic rules were followed.

(1) for each combination of keywords, the first 10 hits were examined. When surfing any of them, no more than four levels of navigation were considered;

(2) when a project was found, it was added to the list together with its contact information. In addition, two new keywords were added to the list, the first one containing the current combination but filtering the name of the project found, using the option "-" (in Google, to exclude pages where the current project was present in 
order to broaden the scope of our search) and the second one composed by the name of the found project and Colombia (for acquiring specific information of each project prior to the interview);

(3) if after one search, less than 10 pages were retrieved and it was impossible to retrieve any new telemedicine project from them, then the next combination was used.

In Step 3, each project manager was contacted by telephone to identify and discard projects which had not actually been carried out. In a second contact, an interview was undertaken to request information about:

(1) the active projects that he or she was managing, including any available evaluations;

(2) other telemedicine projects in the country;

(3) telemedicine experts in Colombia.

If new projects were identified, Step 2.2 was conducted again.

In Step 4, an expert identified by the interviewees was contacted for confirmation about each project. An expert was somebody who was mentioned more times in Step 3.3. If new projects were identified through the expert, then Step 2 was conducted again.

In order to classify the projects, a previously published method [9] was adapted. The information retrieved from projects was classified according to feasibility and impact indicators[10] (see Table 2). The level of evidence for each indicator was rated according to the nine-level categorization[11] shown in Table 3, and recommendations were made by using previously suggested[12] criteria. That is, for levels 1 to 3 , high scientific evidence for recommendation existed; for levels 4 to 7 , sufficient evidence for recommendation existed; and for levels 8 or 9 , the evidence was insufficient.[OK as re-worded?]

\section{Results}

The search process identified 45 different projects. In Step 1, 20 scientific papers were obtained. After reading them, 15 telemedicine projects were identified, and information about Colombian legislation on telemedicine services was also obtained.[13,14]

Step 2 provided information about 16 additional projects, and also provided contact information for the ones that had already been identified. Step 3 allowed us to identify 13 more projects, and to discard 2 (ARCAL 007 [15] and Ecopetrol [2,7]), because they were never carried out. Finally, in Step 4, a list of 42 projects was provided to an expert (an officer from the Communication Office), who confirmed each one and also added a new one, namely the telemedicine activities carried out by ITMS.[16,17]

The 43 resulting projects were classified into two groups: telemedicine research initiatives and projects for providing health care services via telemedicine. The first group included research projects involving the development of hardware and software (such as signal and image processing, telesurgery systems and telemonitoring equipment) for telemedicine projects, which had not yet been validated in patients. The second group consisted of projects in which patients had been managed via telemedicine. A third category was the project from the Colombian Association for Medicine, Informatics and Telehealth itself,[54] which aimed to create a forum where all those involved in telemedicine development in Colombia could exchange ideas and progress. 


\section{Telemedicine research projects}

The search algorithm provided information about 10 research projects. Strictly speaking, they were not projects, but research groups devoted to specific telemedicine activities. Therefore, they were included on a descriptive basis, but they were not considered in the analysis. The 10 research groups were:

(1) the Telemedicine Centre from Universidad Nacional de Colombia (UNC) that began its work in 1996 with Teleamazon[18], a research project to identify those processes within the public health care system in the Amazonas Department that could be improved using telemedicine;

(2) the R \& D in New Telecommunication Technologies Group from Universidad del Cauca that carried out in 1999 a project that laid the foundations for other telemedicine projects in the department of Cauca[19];

(3) the Bioengineering Group from UNC that mainly conducts research in medical image processing (compression and pattern recognition)[20-22];

(4) the Bioengineering Research Group (Grupo de Investigación en Bioingeniería - GIB) from Universidad EAFIT[23] that worked on a project for interchanging medical images using Renata (the national broadband network for academic purposes) infrastructure;

(5) the Colombian Telemedicine Centre (CTC) that conducts research jointly with Universidad Javeriana, mainly related to the development of a virtual platform for surgery[24-32] with educational purposes;

(6) the Clinical Engineering Research Group of the Hospital Universitario La Samaritana, which was carrying out a project for adapting of the PACS and HIS of different Colombian hospitals[15];

(7) the Biomedical Engineering Group (Grupo de Investigación Biomédica-GIB) from the Universidad de los Andes,[33] which was working together with Fundación Santa Fe de Bogotá (FSFB), to propose a methodology for evaluating procedures for digitizing radiology images, and researching on hospital information systems;

(8) the FSFB [34] that was researching about cost-effective methods for teleconsulting regarding suicide risk and sexually transmitted diseases in schools of Bogota;

(9) the Perception and Intelligent Systems Research Group from the Universidad del Valle, which was developing a system to handle second opinions and digital images through the Internet[35];

(10) the Telehealth Research Group from the Universidad de Caldas, that was comparing the efficiency of two methods for teaching the integrated management of childhood illnesses, the conventional one and a virtual course designed by them.[36]

\section{Projects for providing health care services via telemedicine}

A total of 32 projects which provided telemedicine services were identified. Out of them, 14 had been finished, 11 remained active, 4 were being implemented and no data were available about the state of the other 3 (see Table 4). Projects were ordered by their current state, and within each group they were ordered chronologically (the most recent first). Table 4 shows whether the indicators referenced in Table 2 had been evaluated or not in each project, and reflects the level of evidence achieved for each of them (in relation to Table 3 ). Information about medical speciality and telemedicine services provided, patients attended and health care centres connected, was also included; for further information see Rey.[15]

A common feature of all the projects was the lack of studies assessing their performance and 
real impact. Most of entries in Table 4 show insufficient level of scientific evidence, because they came from either descriptive articles (e.g. P8[43] or P15 and P16[46]) or from anecdotes that were mentioned in the interviews. The only two studies reporting sufficient evidence for recommendation consisted of a comparison of technical effectiveness (I1) between tele-ECG devices (developed by institutions 3 and 18, respectively) and traditional ECG. They were carried out in P4[17] and P30[54], and both concluded that their devices had the same diagnostic accuracy as the conventional comparators. Some private companies, such as institutions 2, 4 and 18 (see Table 4), mentioned that they had conducted cost-benefit evaluations of their services, but they could not be published for reasons of commercial confidentiality.

The most commonly assessed indicator was I10 (16 projects), showing that many projects in Colombia aimed at improving the accessibility to the health care system for those who live in deprived areas. Also I8 and I4 had been highly considered. Eight projects showed the reduction produced by telemedicine in the time a patient has to wait for being attended, and 12 projects showed that telemedicine services have a good acceptance, although some telemedicine projects (P3, P9) suffered a lot to be accepted in first stance. It is important to note that despite P18 and P24 reported initial institutional acceptance, projects stopped working once they were transferred to the health care institutions.

Very few studies (5 projects) had analysed the improvement in the diagnostic capacity (I6). In P8, an evaluation showed that second opinion reduced six urgent remissions a year in each health care centre. In P15, the manager stated that in San José de Guaviare Hospital, using the teleconsultation system, 170 remissions were avoided during 12 months of operation. The isolated conditions of the hospital produced savings of more than US\$300,000/year for the state administration. On the other hand, in P16, thousands of dollars were invested and only $0.7 \%$ of the diagnoses were changed.

There was a lack of data assessing the effect of telemedicine on the rest of the indicators, and very few conclusions could be drawn. It is remarkable, for instance, that a bad initial evaluation of the existing technologies had led P29 to be within an 8 years implementation period.[do you mean that P29 had remained stuck in the implementation period for 8 years?] In other cases, unforeseen circumstances ruined some projects, such as P22 and P25, whcih were affected by the economic crisis that struck Colombia at the end of the 1990s.

Institutions providing telemedicine services in Colombia were mostly private, however, public institutions, such as the Colombian government, were also involved in these fields. This was the case of P1 and P2, financed by the Health Office and entrusted to institution 5, 6 and 18 (see Table 4), which aim at improving access to the health care system for those departments lacking in key services for emergency attention.

There was a wide variety of services provided by the projects, ranging from those typical in industrialised countries, such as telecardiology or teleradiology, to those specific to developing regions, such as telemicroscopy for malaria or tuberculosis. Most of the services of telecardiology, teledermatology or teleradiology were provided by teleconsultation using software developed by each institution. In addition, in some services, like teleneumology [is this telehealth for respiratory medicine?] in P4, the institution (see Table 4), had developed their own hardware. 


\section{Discussion}

The present systematic review of telemedicine projects in Colombia allowed us to update and extend earlier studies with new information, hence increasing the number of identified projects from 8 to 45 . The search strategy was efficient and it served to find almost all the telemedicine initiatives with patients developed in Colombia up to May 2008. Under Colombian legislation, it is compulsory to report to the government on the start-up of projects which aim at managing patients through telemedicine, and the expert who was selected in the search strategy was the civil servant responsible for the management of those reports. Therefore, we can consider that the results of the search strategy were validated at least for the second group of projects. Thus, the proposed search strategy may be useful for future systematic reviews of telemedicine projects in countries where information is not easily accessible.

The systematic review has drawn a picture of Colombia, with a lot of institutions, both private and public, including the government, working for the development of the telemedicine in the country through several projects. Among these ones, which vary in scope and provided services, health care services have been provided on a telemedicine basis to, at least 550,000 patients, and they have connected more than 650 health care institutions, mainly in deprived areas of the country. Unfortunately, although many projects seem to have had a positive effect, none of them has been rigorously evaluated, and therefore no general recommendations can be made in the absence of scientific evidence. In future, therefore, it would be advisable that financing agencies consider funding only projects which include a well-designed plan for evaluating their feasibility and impact.

\section{Acknowledgments}

This work was partially supported by grant TEC2007-68096-C02 from the Spanish Government.

\section{References [checked by JL]}

1. Fundación Telefónica. Las TIC y el Sector Salud en Latinoamérica [Information Technologies and Telecommunications in Latinamerican Health Sector]. Madrid: Editorial Ariel, 2008 [pls provide an approximate English translation of the title] [Spanish]

2. Organismo Andino de Salud. Aplicaciones de telecomunicaciones en salud en la subregión andina: Telemedicina. Institutional Document Series. Washington, DC: Organismo Andino de Salud, 2002. See http://www.comunidadandina.org/telec/Documentos/Telecomunicaciones_salud.pdf (last checked 7 September 2009)

3. Ministerio de la Protección Social. Resolución 1448. Diario Oficial, Colombia, 2006, 46332:1-7 [is this a book or a journal article? pls provide an approximate English translation of the title] [Social Protection Ministry, Resolution 1448, Official State XX, Colombia, 2006] [Spanish]

4. Doolittle G, Cook D. Defining the needs of a telemedicine service. In Introduction to Telemedicine. London: Royal Society of Medicine Press, 1999

5. Hailey D, Ohinmaa A, Roine R. Study quality and evidence of benefit in recent assessments of telemedicine. J Telemed Telecare 2004 ; 10: 318-24

6. Vélez JA. Panorama y tendencias de la telemática en salud, hablando de telemedicina. [Landscape and trends of telematics in Health, talking about Telemedicine] Sistemas 
\& Telemática 2004, 2:107-123. ISSN 1692-5238 [pls provide an approximate English translation of the title] [Spanish]

7. Urtubey X, Prieto E, Hope H, Rodrigues R, Van West Charles R. Telehealth in the Americas. Washington DC: Inter-American Telecommunication Commission, Organization of American States, 2004. ISBN 0-8270-4613-8

8. Moser PL, Hauffe H, Lorenz IH, et al. Publication output in telemedicine during the period January 1964 to July 2003. J Telemed Telecare 2004; 10: 72-7

9. Martínez A, Everss E, Rojo-Alvarez JL, Figal DP, García-Alberola A. A systematic review of the literature on home monitoring for patients with heart failure. $J$ Telemed Telecare 2006; 12: 234-41

10. Martınez A, Rodrigues RJ, Infante A, Campillo C, Gattini C. Bases metodológicas para evaluar la viabilidad y el impacto de proyectos de Telemedicina. [Methodological Bases for Evaluating Viability and Impact of Telemedicine Projects] Washington DC: Pan American Health Organization, 2001[pls provide an approximate English translation of the title] [Spanish]

11. Jovell AJ, Navarro-Rubio MD. Evaluation of scientific evidence. Med Clin (Barc) 1995; 105: 740-3 [Spanish]

12. Jovell AJ, Navarro-Rubio MD, Aymerich M, Serra-Prat M. Methodology for the design and development of clinical practice guidelines in primary care. Aten Primaria 1997; 20: 259-62, 264-6. [Spanish]

13. Matiz Camacho H. The future of medicine with equity in Colombia: Telemedicine. Revista Colombiana de Cardiología 2007; 14:1-8

14. Ministerio de la Protección Social. Resolución 2182. Diario Oficial 2004, 45611:1-13 Colombia [is this a book or a journal article? pls provide an approximate English translation of the title] [Social Protection Ministry, Resolution 2182, Official State XX, Colombia, 2004] [Spanish]

15. Rey C. A systematic review of telemedicine projects in Colombia. Master Thesis Dissertation Aalborg University, Denmark, 2008

16. ITMS. See http://www.itms.cl (last checked 7 September 2009)

17. Escobar E, Adriazola P, Castro P, et al. Tele-electrografía experiencia preliminar. In Congreso Chileno de Medicina Interna, 2003

18. Campos J. Proyecto andino-europeo de telemedicina para la amazonía. Revista de Salud Pública 2001; 3: 182-186 ISSN 0124-0064 [pls provide an approximate English translation of the title] [Andian-european telemedicine project for Amazonia] [Spanish]

19. Castillo E, Solarte V. Programa de investigación y desarrollo en redes de acceso universal para la teleeducación y la telemedicina. Telecomunicaciones \& Sociedad 2004, 2:2840, ISSN 17947197 [pls provide an approximate English translation of the title] [Research and development program in universal access network for tele-education and telemedicine] [Spanish]

20. Caicedo JC, González FA, Romero E. Content-based medical image retrieval using lowlevel visual features and modality identification. Lecture Notes in Computer Science 2008; 5152: 615-622

21. Caicedo JC, González FA, Romero E. A semantic content based retrieval method for histopathology images. In Informational Retreival Technology 2008; 4993: 51-60

22. Caicedo JC, González FA, Triana E, Romero E. Design of a medical image database with content-based retrieval capabilities. Advances in Image and Video Technology 2007; 919-931

23. GIB-EAFIT. See

http://www.eafit.edu.co/EafitCn/Investigacion/Grupos/Ingenieria/GIB/IndexGIB.htm 
(last checked 7 September 2009)

24. Vélez Beltrán JA, Newball AA. A virtual educational strategy on telemedicine and medical simulation. Telemed J E Health 2005; 11: 496-9

25. Vélez JA, Navarro AA. Una perspectiva de e-salud en Colombia. RevistaeSalud.com [is this the correct journal name?] 2005; 1(4) [page numbers?] [pls provide an approximate English translation of the title] [An e-health perspective in Colombia][Spanish]

26. Navarro AA, Vélez JA, Satizabal JE, Múnera LE, Bernabe G. Virtual surgical telesimulations in ophthalmology. International Congress Series 2003; 1256: 145-150

27. Navarro AA, Vélez JA, Múnera LE, Bernabe, G. Arquitectura de software basada en la internet para la simulación virtual de cirugía endoscópica otorrinolaringológica [Internet-based Software Architecture for Virtual Simulation of Othorhynolaringological? Endoscopic Surgery ]. Sistemas \& Telemática 2003; 1: 3545 [pls provide an approximate English translation of the title] [][Spanish]

28. Navarro Newball AA, Hernández CJ, Velez JA, et al. Virtual surgical telesimulations in otolaryngology. Stud Health Technol Inform 2005; 111: 353-5

29. Vélez JA, Navarro AA, Múnera LE, Kopec A, García GB. Methodological basis for distributed web testing of surgical simulators prototypes in a telemedicine latin american network (TLAN). Telemedicine Journal and E-Health 2002, 10(Supp I):116

30. Vélez JA, Navarro AA, Múnera LE, García GB. A software architecture for virtual simulation of endoscopic surgery. Telemedicine Journal and E-Health 2002, 8(2):267

31. Vélez JA, Gamboa C. Virtual surgery model: fundamentals on electronic endoscopic otolaryngology web-based scenario. Telemedicine Journal and E-Health 2001, $7(2): 195$

32. Navarro AA, Hernández CJ, Vélez JA, Múnera LE, García GB. A virtual telesimulation scenario for otolaryngologic surgery skills training. Telemedicine Journal and EHealth 2004, 10(Supp I):71

33. GIB-Universidad de los Andes. See http://ingbiomedica.uniandes.edu.co (last checked 7 September 2009)

34. Fundación Santa Fe de Bogotá. See http://www.fsfb.org.co (last checked 7 September 2009)

35. Percepción y Sistemas Inteligentes, Universidad del Valle, Colombia. See http://psi.univalle.edu.co/ (last checked 7 September 2009)

36. Telesalud Universidad de Caldas. See http://telesalud.ucaldas.edu.co/ (last checked 7 September 2009)

37. Centro de Telemedicina-Universidad Nacional de Colombia. See http://www.unal.edu.co/telemedicina/ (last checked 7 September 2009)

38. Fundación CardioVascular de Colombia. See http://www.fcv.org (last checked 7 September 2009)

39. E. Ltda. See http://www.esoftltda.com (last checked 7 September 2009) Unable to open. Cannot locate internet server or proxy server [pls check the URL ...]

40. Valenzuela J, Arguello A, Cendales JG, Rizo CA. Web-based asynchronous teleconsulting for consumers in Colombia: a case study. Journal of Medical Internet Research 2007; 9: e33 See http://doi:10.2196/jmir.9.4.e33

41. Angel DI, Alfonso R, Faizal M, et al. Cutaneous tuberculosis diagnosis in an inhospitable Amazonian region by means of telemedicine and molecular biology. $\mathrm{J}$ Am Acad Dermatol 2005; 52(5 Suppl. 1): S65-8

42. Arbelaez M .El aporte de la telemedicina de la Universidad de Caldas en el fortalecimiento de redes sociales y académicas en el marco de la sociedad del conocimiento [Telemedicine Contribution from Caldas University to Social and 
Academic Networks in the Knowledge Society Framework]. In V Foro Académico de Diseño 2008, Manizales, Colombia [pls provide an approximate English translation of the title] [Spanish]

43. Rendón A, Martínez A, Dulcey MF, et al. Rural telemedicine infrastructure and services in the Department of Cauca, Colombia. Telemed J E Health 2005; 11: 451-9

44. SaludCoop. See http://www.saludcoop.com.co (last checked 7 September 2009)

45. Sachpazidis I, Kiefer S, Selby P, Ohl R, Sakas G. A medical network for teleconsultations in Brazil and Colombia. In Second IASTED International Conference on Telehealth 2006, Banff, AB, Canada, 2006; 16-21

46. Sachpazidis I, Konnis G, Kiefer S, et al. T@lemed: Medical imaging tele-cooperation technologies providing medical services in Latin America. In EMBS/ITAB 2006 [date and place of this conference?] [Spanish]

47. García A, Isaza J, Zapata U, Roldán A. Ejecución de un sistema piloto de tele-radiología en Medellín [A Tele-radiology Pilot System Asessment in Medellín], Colombia. Colombia Médica 2006; 37: 183-188 [pls provide an approximate English translation of the title] [Spanish]

48. Castillo E, Solarte V. Red Piloto de Teleasistencia Sanitaria [Health Teleassistance Pilot Network]. Telecomunicaciones \& Sociedad 2004, 2:5-27, ISSN 17947197 [pls provide an approximate English translation of the title] [Spanish]

49. Benítez, H. Experiencia del seguro social colombiano en telerradiología [Colombian Social Security Experience in Tele-radiology]. Revista de Salud Pública 2001, 3 (Suppl 1):187-193, ISSN 0124-0064 [pls provide an approximate English translation of the title] [Spanish]

50. GITEM-Universidad Francisco José de Caldas. See http://gemini.udistrital.edu.co/comunidad/grupos/gitem/ (last checked 7 September 2009)

51. Velez Beltran JA, Newball AA. A Latin American telemedicine social perspective from a Colombian telemedicine center initiative. Telemed J E Health 2005; 11: 616-9

52. Vélez B JA, Navarro Newball AA, Ricur G. Telemedicine in the Latin American and Caribbean regions: the Cartagena telemedicine conference. J Telemed Telecare 2007; 13: $210-1$

53. Cardona O, Mejía S, Castrillón J, Giraldo D, Jaramillo A, Bustamante J. Interfaz para equipos de monitoreo médico (Red de Telemedicina de Antioquía) [Interface for Medical Monitoring Equipments (Antioquía Telemedicine Network)]. In VI Congreso de la Sociedad Cubana de Bioingeniería 2005, Habana, Cuba [pls provide an approximate English translation of the title] [Spanish]

54. Miserque NIC, Camacho P, Arenas W, Quiroz R, Rueda J. Estudio Símil ECG: Estudio de Concordancia entre la Electrocardiografía Convencional y la Electrocardiografía Digital utilizando Internet y la Web como medio de transmisión en Telemedicina [Study on Concordance Between Traditional and Digital Electrocardiography Using Internet and the Web as a Telemedicine Transmission Medium]. Revistaesalud.com 2006; 2(7). ISSN 1698-7969 [is this a book or a journal article? pls provide an approximate English translation of the title] [Spanish]

55. Miserque NIC. Programa Galaxia Fundación Cardiovascular de Colombia [Galaxy Program from Colombian Cardiovascular XX]. Revistaesalud.com 2005; 1(4). ISSN 1698-7969 [is this a book or a journal article? pls provide an approximate English translation of the title] [Spanish]

56. Díaz D. See http://www.drgdiaz.com (last checked 7 September 2009) 
Table 1. Keywords used for web search

1. "telemedicine in Colombia"

2. "telemedicine project" Colombia site:.org OR site:.co

3. "telemedicine project" Colombia

4. telemedicine project Colombia site:..org OR site:.co

5. telemedicine project Colombia

6. "telemedicine congress" Colombia

7. telemedicine congress Colombia site:.org OR site:.co

8. telemedicine congress Colombia

9. "health office" telemedicine Colombia site:.co OR site:.gob

10. medicine office OR health telemedicine Colombia site:.co OR site:.gob

11. "health office" telemedicine Colombia

12. "health office" Colombia

13. "faculty of medicine" telemedicine Colombia

14. university OR faculty telemedicine Colombia site:.org OR site:.co

15. university OR faculty telemedicine Colombia 
Table 2. Evaluated feasibility and impact indicators

\begin{tabular}{|c|c|c|}
\hline Indicators & $\begin{array}{l}\text { La } \\
\text { bel }\end{array}$ & Description \\
\hline \multicolumn{3}{|l|}{ Feasibility } \\
\hline \multirow[t]{3}{*}{ Technical } & I1 & $\begin{array}{l}\text { Effectiveness. Effectiveness indicates whether the technical features of a telemedicine system } \\
\text { were sufficient to provide the health service they were designed for. Articles or data which } \\
\text { included comparisons between data obtained through telemedicine systems and those obtained } \\
\text { through "traditional" methods have been recalled.[what does this mean?] }\end{array}$ \\
\hline & I2 & $\begin{array}{l}\text { Reliability. Reliability refers to robustness and security. Robustness refers to the rate of system } \\
\text { breakdown; while security refers to the avoidance of undesired side effects caused by the use of } \\
\text { a telemedicine system, such as protection against data loss. }\end{array}$ \\
\hline & I3 & $\begin{array}{l}\text { Ease of use. This refers to the simplicity of handling the telemedicine system and its adaptation } \\
\text { to the daily work of the institutions where it has been deployed. }\end{array}$ \\
\hline Institutional & I4 & $\begin{array}{l}\text { Acceptance. Acceptance is based on evidence from patients, health workers and health } \\
\text { authorities about their satisfaction with the introduction of the telemedicine system. }\end{array}$ \\
\hline Economic & I5 & $\begin{array}{l}\text { Sustainability: This concerns the financial evidence that a telemedicine system can be } \\
\text { maintained by the health institution concerned. }\end{array}$ \\
\hline \multicolumn{3}{|l|}{ Impact } \\
\hline \multirow[t]{2}{*}{ Clinical process } & I6 & $\begin{array}{l}\text { Improvement in diagnosis capacity: This indicator is intended to measure whether a relationship } \\
\text { exists between using a telemedicine system and improving the quality of diagnosis. }\end{array}$ \\
\hline & I7 & $\begin{array}{l}\text { Changes in organization. This assesses whether a new system always brings changes in the way } \\
\text { an institution is organized. }\end{array}$ \\
\hline Patient health & I8 & $\begin{array}{l}\text { Utility: This refers to changes in the patient's mental and emotional welfare, i.e. anything which } \\
\text { means an improvement of the patient's quality of life. }\end{array}$ \\
\hline \multirow[t]{2}{*}{ Accessibility } & I9 & $\begin{array}{l}\text { Perception of isolation: This considers any reduction in the feeling of isolation experienced by } \\
\text { patients and health care workers. }\end{array}$ \\
\hline & $\mathrm{I} 10$ & $\begin{array}{l}\text { [what is this one called?] To a higher quality health care system: It considers data showing that } \\
\text { new disciplines have been extended to remote areas or the protocol for emergencies has been } \\
\text { improved. }\end{array}$ \\
\hline \multirow[t]{2}{*}{ Economic } & I11 & $\begin{array}{l}\text { [what is this one called?] On the health care centre. It refers to the cost-benefit analysis of the } \\
\text { installation of a telemedicine system. }\end{array}$ \\
\hline & $\mathrm{I} 12$ & $\begin{array}{l}\text { [what is this one called?] On the health care national system. It takes into account studies or } \\
\text { data referring to the economic impact of improving coverage through telemedicine at a national } \\
\text { level. }\end{array}$ \\
\hline
\end{tabular}


Table 3. Classification of finding [is this Level the wrong way round? Isn't Level 1 the worst and Level 9 the best in the original paper by Jovell AJ and Navarro-Rubio MD?]

\begin{tabular}{|c|l|l|}
\hline $\begin{array}{c}\text { Level of } \\
\text { evidence }\end{array}$ & $\begin{array}{l}\text { Strength of } \\
\text { evidence }\end{array}$ & Study design \\
\hline 1 & Very good & Meta-analysis \\
\hline 2 & Very good & Large sample randomized controlled trials \\
\hline 3 & Good & Large sample randomized controlled trials \\
\hline 4 & Good & Non-randomized controlled prospective studies (multicentre) \\
\hline 5 & Fair & Non-randomized controlled prospective studies \\
\hline 6 & Fair & Cohort studies \\
\hline 7 & Fair & Case-control studies \\
\hline 8 & Poor & Non-controlled clinical series, descriptive studies \\
\hline 9 & Poor & Anecdotes or case reports \\
\hline
\end{tabular}


Table 4. Characteristics of selected studies and evaluated indicators

\begin{tabular}{|c|c|c|c|c|c|c|c|c|c|c|c|c|c|c|c|c|c|c|c|}
\hline \multirow{3}{*}{ Project } & \multicolumn{12}{|c|}{ Evaluation indicators } & \multirow{3}{*}{$\begin{array}{l}\text { In } \\
\text { st }\end{array}$} & \multirow{3}{*}{ Beg } & \multirow{3}{*}{ Fin } & \multirow{3}{*}{$\begin{array}{c}\text { Medical } \\
\text { specialit } \\
\mathbf{y} \\
\end{array}$} & \multirow{3}{*}{$\begin{array}{l}\text { Telemed } \\
\text { service }\end{array}$} & \multirow{3}{*}{$\begin{array}{c}\mathrm{N}^{\mathrm{a}} \\
\text { patients }\end{array}$} & \multirow{3}{*}{$N^{a}$ centers } \\
\hline & \multicolumn{5}{|c|}{ Feasibility } & \multicolumn{7}{|c|}{ Impact } & & & & & & & \\
\hline & 1 & 2 & 3 & 4 & 5 & 6 & 7 & 8 & 9 & 10 & 11 & 12 & & & & & & & \\
\hline P1 Basic services ${ }^{37,38}$ & & & & & & & & IX & & IX & & & 1 & $\begin{array}{c}200 \\
8\end{array}$ & Act & $\begin{array}{c}\text { C, N, } \\
\text { IM, P, G, } \\
\text { U, O, D, } \\
\text { I, OR }\end{array}$ & $\mathrm{TC}$ & 3026 & 58 \\
\hline $\begin{array}{l}\text { P2 Intermediate } \\
\text { services }^{37,38}\end{array}$ & & & & & & & & IX & & IX & & & & $\begin{array}{c}200 \\
8\end{array}$ & Act & GM & TM, TEI & 245 & 11 \\
\hline $\begin{array}{l}\text { P3 Medical } \\
\text { Management }\end{array}$ & & IX & & IX & & & IX & IX & & & & & 2 & $\begin{array}{c}200 \\
7\end{array}$ & Act & ND & TA & ND & 2 \\
\hline $\begin{array}{l}\text { P4 ITMS- } \\
\text { Colombia }^{16,17}\end{array}$ & $\begin{array}{l}\mathrm{V} \\
\mathrm{I}\end{array}$ & & & IX & & & IX & & & & & & 3 & $\begin{array}{c}200 \\
7\end{array}$ & Act & $\mathrm{C}, \mathrm{PN}$ & TC,TM & 30000 & 135 \\
\hline P5 Doctor Chat ${ }^{40}$ & & & & IX & & & & IX & & IX & & & 4 & $\begin{array}{c}200 \\
6\end{array}$ & Act & GM & TEI & 1200 & 1 \\
\hline P6 Leticia Clinic ${ }^{41}$ & & & IX & & & & & IX & & IX & & & 5 & $\begin{array}{c}200 \\
5\end{array}$ & Act & $\begin{array}{c}\mathrm{C}, \mathrm{IM}, \\
\mathrm{U}, \mathrm{O}, \mathrm{P}, \\
\mathrm{D}, \mathrm{R}, \\
\mathrm{PA}, \mathrm{H}\end{array}$ & $\mathrm{TC}$ & 2082 & 1 \\
\hline P7 Teledermatology 42 & & & IX & IX & IX & & & IX & & IX & & & 6 & $\begin{array}{c}200 \\
2\end{array}$ & Act & $\mathrm{D}$ & $\mathrm{TC}$ & 2727 & 25 \\
\hline P8 EHAS-Colombia ${ }^{43}$ & & & $\begin{array}{l}\text { VI } \\
\text { II }\end{array}$ & $\begin{array}{l}\text { VI } \\
\text { II }\end{array}$ & & $\begin{array}{l}\text { VI } \\
\text { II }\end{array}$ & $\begin{array}{l}\text { VI } \\
\text { II }\end{array}$ & & $\begin{array}{l}\text { VI } \\
\text { II }\end{array}$ & \begin{tabular}{|l} 
VI \\
II
\end{tabular} & IX & IX & 7 & $\begin{array}{c}200 \\
2\end{array}$ & Act & GM & $\begin{array}{l}\text { TC, TE, } \\
\text { TA, O }\end{array}$ & ND & 31 \\
\hline $\begin{array}{l}\text { P9 Telemedicine Salud } \\
\text { Coop }^{44}\end{array}$ & & & & IX & & & IX & & & IX & & & 8 & $\begin{array}{c}200 \\
2\end{array}$ & Act & $\begin{array}{l}\text { P,G,GA, } \\
\text { C,N,ON, } \\
\text { OR,E,PN }\end{array}$ & $\mathrm{TC}$ & 21581 & 22 \\
\hline P10 Teleradiology ${ }^{2}$ & & & & & & & & & & & & & 6 & ND & Act & $\mathrm{R}$ & $\mathrm{TC}$ & 150 & 25 \\
\hline P11 Virtual Clinics ${ }^{34}$ & & & & & & & & & & & & & 4 & ND & Act & GM & TE, TEI & ND & 3 \\
\hline P12 Teledermatolgy ${ }^{34}$ & & & & IX & & & & & & & & & 4 & $\begin{array}{c}200 \\
7\end{array}$ & $\begin{array}{c}200 \\
8\end{array}$ & $\mathrm{D}$ & $\mathrm{TC}$ & ND & 29 \\
\hline
\end{tabular}




\begin{tabular}{|c|c|c|c|c|c|c|c|c|c|c|c|c|c|c|c|c|c|c|}
\hline $\begin{array}{l}\text { P13 San José del } \\
\text { Guaviare (now P1 and } \\
\text { P2) }\end{array}$ & & & & IX & & & & IX & IX & & IX & \multirow{3}{*}{5} & $\begin{array}{c}200 \\
7\end{array}$ & $\begin{array}{c}200 \\
8\end{array}$ & $\begin{array}{l}\text { C, IM, G, } \\
\text { U, O, D, } \\
\text { I, R, H }\end{array}$ & $\mathrm{TC}$ & 3575 & 1 \\
\hline P14 Ríohacha ${ }^{37}$ & & & & & & & & & IX & & & & $\begin{array}{c}200 \\
7\end{array}$ & $\begin{array}{c}200 \\
8\end{array}$ & $\mathrm{D}, \mathrm{R}, \mathrm{I}$ & $\mathrm{TC}$ & 1815 & 1 \\
\hline $\begin{array}{l}\text { P15 T@lemed } \\
\text { Guaviare (seed of P10 } \\
13 \text { and P11) }\end{array}$ & $\begin{array}{l}\mathrm{I} \\
\mathrm{X}\end{array}$ & IX & IX & & & IX & & IX & IX & IX & IX & & $\begin{array}{c}200 \\
5\end{array}$ & $\begin{array}{c}200 \\
7\end{array}$ & R,D,G,I & $\mathrm{TC}$ & 1720 & 2 \\
\hline $\begin{array}{l}\text { P16 T@lemed Costa } \\
\text { Pacifica }\end{array}$ & \begin{tabular}{|l|}
$\mathrm{I}$ \\
$\mathrm{X}$ \\
\end{tabular} & & & & IX & IX & & & IX & & & 9 & $\begin{array}{c}200 \\
5\end{array}$ & $\begin{array}{c}200 \\
6 \\
\end{array}$ & I & $\mathrm{TC}$ & $43 I X$ & 3 \\
\hline $\begin{array}{l}\text { P17 Teleradiology } \\
\text { Medellín }^{47}\end{array}$ & $\begin{array}{l}\mathrm{I} \\
\mathrm{X}\end{array}$ & & & & & & & & & & & 10 & $\begin{array}{c}200 \\
4\end{array}$ & $\begin{array}{c}200 \\
5\end{array}$ & $\mathrm{R}$ & $\mathrm{TC}$ & ND & 2 \\
\hline $\mathrm{P} 18 \mathrm{ReTaS}^{48}$ & & IX & & IX & & & & & & & & 7 & $\begin{array}{c}200 \\
3\end{array}$ & $\begin{array}{c}200 \\
4\end{array}$ & I & $\mathrm{TC}, \mathrm{TEI}$ & ND & 8 \\
\hline $\begin{array}{l}\text { P19 Bogóta-San } \\
\text { Andrés-Providencia }{ }^{2,7}\end{array}$ & & & & & & & & & IX & IX & & \multirow{2}{*}{5} & $\begin{array}{c}200 \\
0\end{array}$ & $\begin{array}{c}200 \\
6 \\
\end{array}$ & $\begin{array}{c}\mathrm{O}, \mathrm{R}, \mathrm{C}, \mathrm{G}, \\
\mathrm{D}\end{array}$ & $\mathrm{TC}$ & ND & 2 \\
\hline $\begin{array}{l}\text { P20 Bogóta-Apaporis- } \\
\text { Leticia }^{2,7}\end{array}$ & & & & IX & & & & & IX & IX & & & $\begin{array}{c}200 \\
0\end{array}$ & $\begin{array}{c}200 \\
3\end{array}$ & $\begin{array}{l}\mathrm{O}, \mathrm{R}, \mathrm{C}, \mathrm{G} \\
\mathrm{D}\end{array}$ & $\mathrm{TC}$ & ND & 2 \\
\hline $\begin{array}{l}\text { P21 Telematics } \\
\text { Network }^{15}\end{array}$ & & & & & & & & & IX & & & 7 & $\begin{array}{c}200 \\
0\end{array}$ & $\begin{array}{c}200 \\
1 \\
\end{array}$ & ND & TA & ND & 1 \\
\hline $\begin{array}{l}\text { P22 Teleradiology - } \\
\text { VTG }^{2}\end{array}$ & & & & & & & & & & & & \multirow{2}{*}{11} & $\begin{array}{c}199 \\
9\end{array}$ & $\begin{array}{c}200 \\
2\end{array}$ & $\mathrm{R}$ & $\mathrm{TC}$ & 300000 & 29 \\
\hline $\begin{array}{l}\text { P23 Teleradiology- } \\
\text { ISS }^{49}\end{array}$ & & & IX & & & & & & & $\begin{array}{l}\text { VI } \\
\text { II }\end{array}$ & & & $\begin{array}{c}199 \\
7\end{array}$ & $\begin{array}{c}199 \\
9\end{array}$ & $\mathrm{R}$ & $\mathrm{TC}$ & 173125 & 10 \\
\hline $\begin{array}{l}\text { P24 Cundinamarca } \\
\text { Telemedicine } \\
\text { Network }^{15}\end{array}$ & & & & IX & & IX & IX & & & IX & & 12 & $\begin{array}{c}199 \\
5\end{array}$ & $\begin{array}{c}199 \\
6\end{array}$ & $\mathrm{R}$ & $\mathrm{TC}$ & 2754 & 5 \\
\hline $\begin{array}{l}\text { P25 Cardiac } \\
\text { Telemetric Network }{ }^{2}\end{array}$ & & & & IX & & IX & & & & & & 13 & $\begin{array}{c}199 \\
4\end{array}$ & $\begin{array}{c}200 \\
2\end{array}$ & $\mathrm{C}$ & $\mathrm{TC}$ & ND & 113 \\
\hline P26 Telemap ${ }^{15}$ & & & & & & & & & & & & 14 & $\begin{array}{c}200 \\
8\end{array}$ & Imp & $\mathrm{P}, \mathrm{OR}, \mathrm{C}$ & $\begin{array}{l}\text { TC, TE, } \\
\text { TM, TEI }\end{array}$ & DNA & DNA \\
\hline $\begin{array}{l}\text { P } 27 \text { Health } \\
\text { Management }^{50}\end{array}$ & & & & & & & & & & & & 15 & $\begin{array}{c}200 \\
8\end{array}$ & Imp & ND & $\mathrm{TA}$ & DNA & DNA \\
\hline P 28 Rehab Land & & & & & & & & & & & & 16 & 200 & Imp & PS, OR & $\mathrm{TC}, \mathrm{TM}$ & DNA & DNA \\
\hline
\end{tabular}




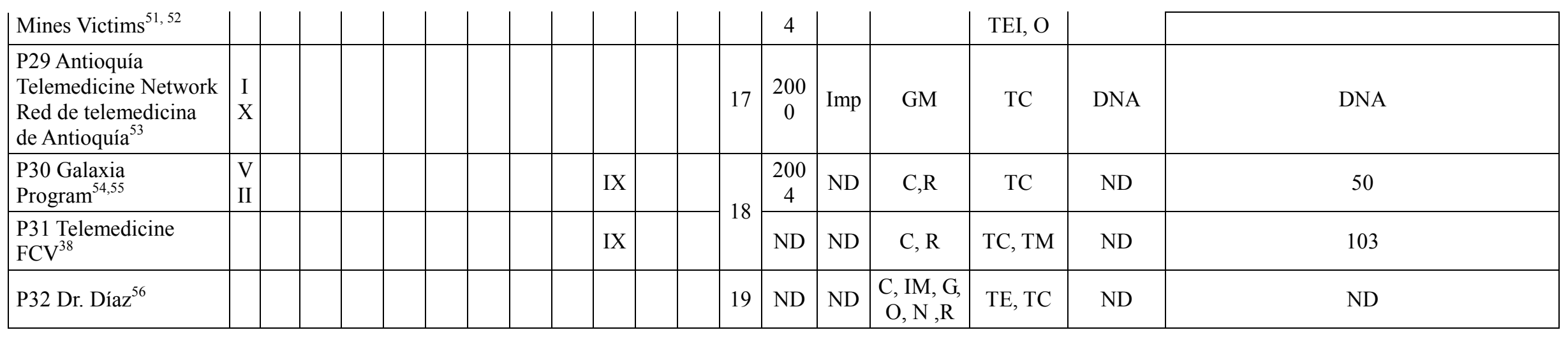

Institutions: Pu (public); Pr (private), (1) Caprecom (Pu); (2) Esoft Ltd (Pr), (3) ITMS-Colombia (Pr), (4) Fundación Santa Fe de Bogotá (Pr), (5) Telemedicine Centre-Universidad Nacional de Colombia(Pu) (6) Telehealth Research Group(GIT)-Universidad de Caldas (Pu), (7) Universidad del Cauca (Pu), (8) SaludCoop (Pr), (9) Universidad de Cali (Pr), (10) Bioengineering Research Group (GIB)-Universidad EAFIT (Pr), (11) Vision Technology Group (Pr), (12) Hospital Universitario La Samaritana (Pr), (13) Cardiobip Ltd (Pr), (14) Medicine Faculty-Universidad de Antioquía (Pu), (15) Telemedicine Research Group (GITEM)- Universidad Francisco José de Caldas (Pu), (16) Colombian Telemedicine Centre (Pr), (17) Interdisciplinary Telemedicine Team (EIT) - Universidad Pontificia Bolivariana (Pr), (18) Fundación CardioVascular de Colombia (Pr), (19) Dr. Díaz (Pr)

Project situation: End: End; Act: Active, Imp: Implementation Process

Medical specialties: C (cardiology); R (radiology); D (dermatology), N (neurology), PS (psychiatry), G (gynaecology); PN (respiratory); U (urology); O (otorhinolaringology); EN (endocrinology); OR (orthopaedics); ON (oncology); GA (gastroenterology); IM (internal medicine); P (paediatrics); GM (general medicine), I (infectious diseases); PA: pathology and H: haematology

Telemedicine services: TC: teleconsultation between medical staff; TM: telemonitoring of vital signs of patients with chronic diseases (at home or in hospital); TEI: teleeducation in health for people/patients; TE: teleeducation (remote training, support to medical students/healthcare staff, continuing education); TA: teleadministration (remote administration process as citation management); O: other telemedicine services (e.g. epidemiology surveillance)

Others: ND: No data; DNA: Did not apply 